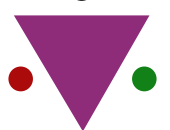

IJCRR

Section: Healthcare Sci. Journal Impact Factor: $6.1(2018)$ ICV: 90.90 (2018)

(c) (1) (9)

Copyright@IJCRR

\title{
Awareness of Infection Control From nCOVID-19 - A Survey Among Denture Wearers
}

\section{S. Padmaja ${ }^{1}$, Subhabrata Maiti², Vinay Sivaswamy ${ }^{3}$}

'Saveetha Dental College and Hospitals, Saveetha Institute of Medical and Technical Sciences, Saveetha University, Chennai-77, Tamilnadu, India; 'Senior Lecturer, Department of Prosthodontics, Saveetha Dental college and Hospitals, Saveetha lnstitute of Medical and Technical Sciences, Saveetha University, Chennai-77, Tamilnadu, India; 3Senior Lecturer, Department of Prosthodontics, Saveetha Dental college and Hospitals, Saveetha Institute of Medical and Technical Sciences, Saveetha University, Chennai-77, Tamilnadu, India.

\section{ABSTRACT}

Background: Complete denture is prosthesis to replace the lost tooth structures and restore aesthetics and function. COVID-19 is a spreading pandemic. COVID-19 mostly affects the people in the elderly age group who have less immunity power according to previous research conducted. So it leads to more risk among those people.

Aim: This survey is conducted to know the awareness level among older people regarding COVID-19. This tests their knowledge of infection control of COVID-19 and the hygiene measures they follow to disinfect the dentures.

Material and Method: Validated questionnaires were prepared and circulated among the patients via social media. Their responses were collected in Google forms. The responses were collected. It depicts if they follow proper oral hygiene like mouthwash usage, hand hygiene while handling dentures. If they had any medical conditions and were aware of how it could affect them in lack of infection control.

Result: Nearly half of our population was aware of the infection control methods. But still, some of them have to be made aware of the infection control.

Key Words: Complete denture, Denture wearer, COVID-19, Infection control, Hygiene methods, Mouthwash.

\section{INTRODUCTION}

A complete denture is prosthesis to replace the lost teeth and restore esthetics and function. ${ }^{1}$ When we do construct a complete denture it is important to determine the correlation of the maxillary anterior teeth ${ }^{2,3}$. As age changes occur in individuals, the use of complete dentures varies. The medical conditions in complete denture wearers can be hypertension, diabetes, or any other systemic disease. The faultiness of dentures or improper handling of dentures increases the risk of infection. Oral hygiene is important to be maintained in people using dentures ${ }^{4,5}$. COVID-19 is the new strain that is introduced in 2020. It is more prone to individuals who have decreased immunity that is especially in the elderly population. Since mostly old age people prefer complete dentures, it leads to more risk on them. COVID-19 is transmitted by droplets contact. So, proper infection control is required to prevent cross-infection. When hygiene control is not properly maintained it can lead to infection occurrence ${ }^{6,7,8}$.
Denture wearers are at high risk due to the possibility of aerosols. Through saliva which is the main aerosol of denture wearers, it can get transmitted easily ${ }^{9}$. When droplets are inhaled or if they come in contact with skin and mucous membranes and get lodged, they contaminate hands. Proper maintenance of denture is needed to prevent the risk of COVID-19. Mouth wash which consists of chlorhexidine can be used as a cleansing agent to provide hygiene to the denture. Denture shape is maintained by soaking in water. They can be added with some cleansing tablets which will protect them from COVID-19 after alcohol rinse. Proper hygiene is required to prevent infection of COVID-19. Since COVID-19 can be transmitted through droplets and air it is safe to keep dentures in a closed box. To prevent contamination, before and after wearing denture it is wiser to use a hand sanitizer, this contains alcohol so that it can destroy the pathogen.

SARS-COV is similar to corona. It was also transmitted through aerosol like saliva. It was also transmitted through

\section{Corresponding Author:}

Dr. Subhabrata Maiti, Senior Lecturer, Department of Prosthodontics, Saveetha Dental college and Hospitals, Saveetha Institute of Medical and Technical Sciences, Saveetha University, Chennai-77, Tamilnadu, India; Phone: 9007862704; Email: subhabratamaiti.sdc@saveetha.com

ISSN: $2231-2196$ (Print)

Received: 25.07 .2020
ISSN: 0975-5241 (Online)

Revised: 20.08 .2020
Accepted: 24.09 .2020
Published: 20.10 .2020 
bloodborne and contaminated the dental water unit line also. The lacuna found in this study was it was not able to stop the spread of infection even after protocols were undertaken. This virus also affects the lungs ${ }^{10}$. Now similarly SARSCOV-2 is also transmitted in the same manner and affects the respiratory organ ${ }^{11}$. The effect of aging in the elderly population is they have diminished production of $\mathrm{T}$ cells and $\mathrm{B}$ cells from thymus and bone marrow. So they are not able to produce an immune response as rapidly and efficient as the younger generation. ${ }^{12-17}$ Aim of this study is to understand how infection control can protect us from COVID-19 which previous studies failed to deliver. It also helps us how to protect the old people from the spreading infection, who also additionally suffer from decreased immunity, which is a risk factor for COVID ${ }^{18,19}$. COVID-19 also is transmitted through droplets which make us be even more careful in protecting ourselves. They are transmitted through the air so they can easily infect the dentures which patients use and are required to keep it in a closed box so that they are not contaminated. This survey is conducted to know the awareness level among older people regarding COVID-19. This tests their knowledge of infection control of COVID-19 and the hygiene measures they follow to disinfect the dentures.

\section{MATERIALS AND METHODS}

80 denture wearers were selected randomly for the study. Approval for the study was obtained from the Institutional Review Board (SRB/SDC/BDS/002/02). The questionnaire was prepared and disseminated using Google forms online response collection software. The questionnaire was validated by 5 prosthodontist lecturers. IBM SPSS version 20.0 software was used for data analysis.

\section{STATISTICAL ANALYSIS}

The dependent variable is infection control from COVID-19. The independent variables are age and sex. The statistical test used was the Chi-square test.

\section{RESULTS AND DISCUSSION}

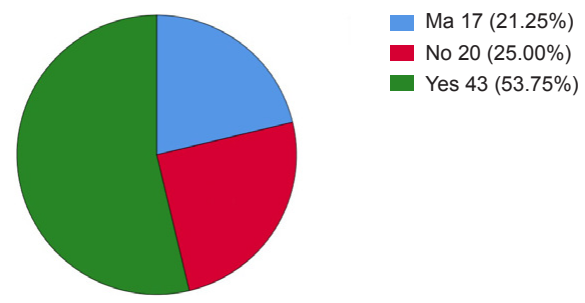

Figure 1: Awareness of COVID-19 travelling through droplets. This Figure shows that $53.75 \%$ were aware of it and $25 \%$ were not aware while $21.25 \%$ were not sure if COVID-19 infection can spread through droplets.

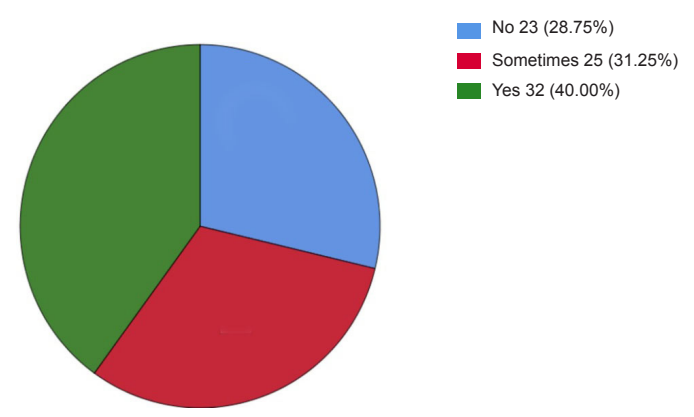

Figure 2: People who use mouthwash. $40 \%$ use mouthwash regularly while $31.25 \%$ use it occasionally. $28.75 \%$ don't use mouthwash. This shows the maintenance of oral hygiene among patients.

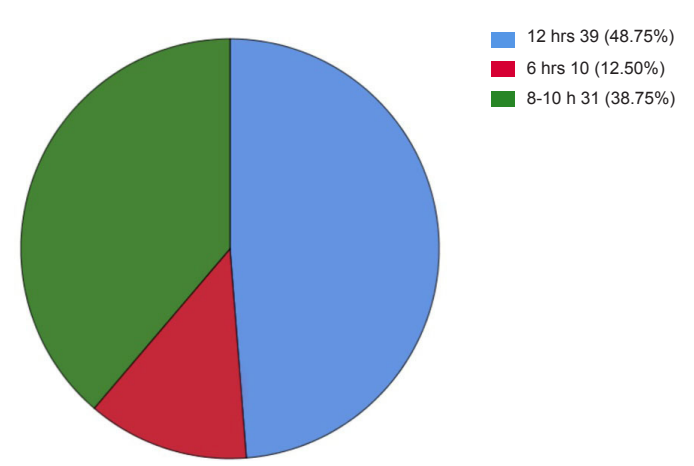

Figure 3: How often do they change the water. Nearly, $48.75 \%$; that is half of the population change water every 12 hours while $12.5 \%$ change it every 6 hours. $38.75 \%$ of the population changes it every 8-10 hours.

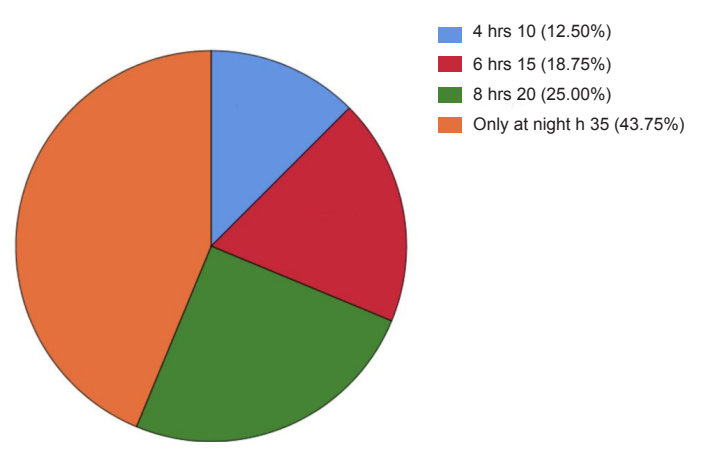

Figure 4: How often do they remove the denture. Nearly $43.75 \%$ remove denture only at night while $12.5 \%$ remove it for every 4 hours once; $18.75 \%$ for every 6 hrs and $25 \%$ for every 8 hours. Each and every time while removing dentures it is essential to maintain hand hygiene to prevent contamination of dentures. 


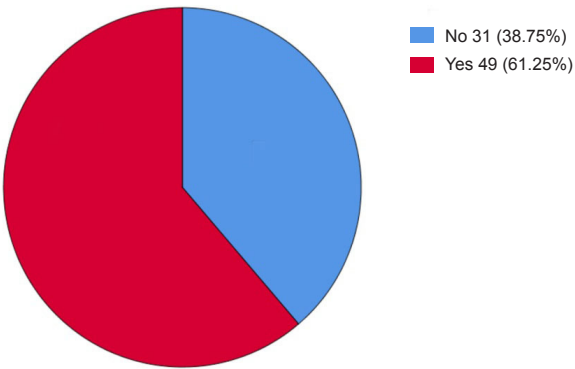

Figure 5: Do they keep dentures in a closed box. Nearly $61.25 \%$ keep it in a closed box to prevent infection through droplets while $30.75 \%$ do not keep it in a closed box.

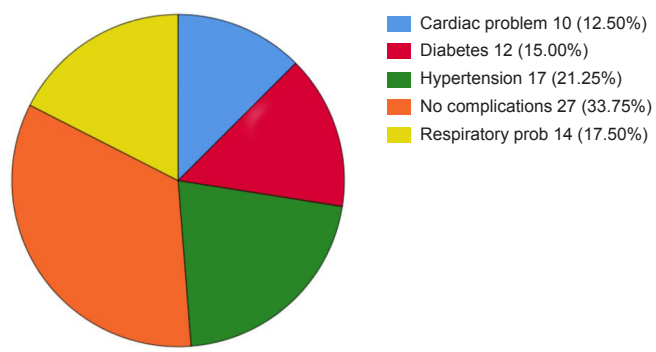

Figure 6: People with medical conditions. Nearly, $17.50 \%$ have respiratory problems, $12.50 \%$ have cardiac problems, $15 \%$ have diabetes, $21.25 \%$ have hypertension and $33.75 \%$ have no complications. This is proving that most of people have medical issues and they have to maintain proper hygiene control to protect themselves from COVID-19 as they already have low immunity and are at high risk of getting infected.

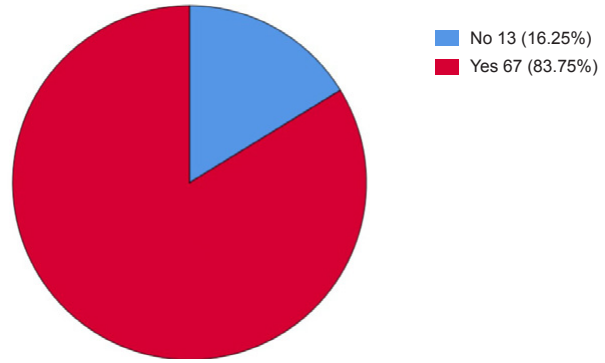

Figure 7: Awareness of people with medical conditions. Nearly $83.75 \%$ were aware that when they have medical conditions they are at high risk to COVID-19 while $16.25 \%$ are not aware of it.

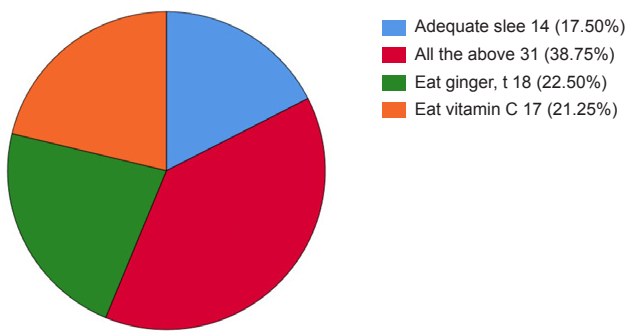

Figure 8: Methods to improve immunity. Nearly $21.25 \%$ eat vitamin $\mathrm{C}$ food and improve immunity. $22.50 \%$ eat ginger-like food items to improve immunity while $17.5 \%$ have adequate sleep as a method. $38.75 \%$ of the population thinks that all the above methods are important to improve immunity and follow them all.

Table 1: This table shows the cumulative response to each question along with the Chi-square test value and P-value.

\begin{tabular}{|c|c|c|c|c|c|c|}
\hline Question & Option & $\begin{array}{l}\text { Response by } \\
\text { female }\end{array}$ & $\begin{array}{l}\text { Response by } \\
\text { male }\end{array}$ & $\begin{array}{l}\text { Cumulative } \\
\text { response }\end{array}$ & Chi-square test & P-value \\
\hline $\begin{array}{l}\text { Are you aware that } \\
\text { COVID-19 travels } \\
\text { through droplets }\end{array}$ & $\begin{array}{l}\text { Maybe } \\
\text { Yes } \\
\text { no }\end{array}$ & $\begin{array}{c}7 \\
20 \\
9\end{array}$ & $\begin{array}{l}10 \\
23 \\
11\end{array}$ & $\begin{array}{l}21.3 \\
46.3 \\
100\end{array}$ & 0.140 & 0.932 \\
\hline $\begin{array}{l}\text { Do you use mouth- } \\
\text { wash }\end{array}$ & $\begin{array}{l}\text { No } \\
\text { yes }\end{array}$ & $\begin{array}{l}12 \\
16\end{array}$ & $\begin{array}{l}11 \\
16\end{array}$ & $\begin{array}{l}28.7 \\
100\end{array}$ & 2.509 & 0.285 \\
\hline $\begin{array}{l}\text { How often do you } \\
\text { change water }\end{array}$ & $\begin{array}{l}\text { 12hrs } \\
6 \text { hrs } \\
\text { 8-10hrs }\end{array}$ & $\begin{array}{c}14 \\
2 \\
20\end{array}$ & $\begin{array}{c}25 \\
8 \\
11\end{array}$ & $\begin{array}{l}48.8 \\
61.3 \\
100\end{array}$ & 8.601 & 0.014 \\
\hline $\begin{array}{l}\text { How often do you } \\
\text { remove dentures }\end{array}$ & $\begin{array}{l}\text { 4hrs } \\
6 \mathrm{hrs} \\
8 \mathrm{hrs} \\
\text { Only at night }\end{array}$ & $\begin{array}{c}5 \\
8 \\
9 \\
14\end{array}$ & $\begin{array}{c}5 \\
7 \\
11 \\
21\end{array}$ & $\begin{array}{l}12.5 \\
31.3 \\
56.3 \\
100\end{array}$ & 0.875 & 0.831 \\
\hline $\begin{array}{l}\text { Do you keep denture } \\
\text { in closed box }\end{array}$ & $\begin{array}{l}\text { No } \\
\text { yes }\end{array}$ & $\begin{array}{l}17 \\
19\end{array}$ & $\begin{array}{l}14 \\
30\end{array}$ & $\begin{array}{c}38.8 \\
100\end{array}$ & 1.980 & 0.159 \\
\hline $\begin{array}{l}\text { Do you have medical } \\
\text { conditions }\end{array}$ & $\begin{array}{l}\text { cardiac } \\
\text { diabetes } \\
\text { High BP } \\
\text { No issue } \\
\text { Resp }\end{array}$ & $\begin{array}{c}1 \\
5 \\
8 \\
14 \\
8\end{array}$ & $\begin{array}{c}9 \\
7 \\
9 \\
13 \\
6\end{array}$ & $\begin{array}{l}12.5 \\
27.5 \\
48.8 \\
82.5 \\
100\end{array}$ & 6.379 & 0.173 \\
\hline
\end{tabular}


Table 1: (Continued)

\begin{tabular}{|c|c|c|c|c|c|c|}
\hline Question & Option & $\begin{array}{l}\text { Response by } \\
\text { female }\end{array}$ & $\begin{array}{l}\text { Response by } \\
\text { male }\end{array}$ & $\begin{array}{l}\text { Cumulative } \\
\text { response }\end{array}$ & Chi-square test & P-value \\
\hline \multirow{2}{*}{$\begin{array}{l}\text { Are you people aware } \\
\text { that these medical } \\
\text { conditions are highly } \\
\text { susceptible to COV- } \\
\text { ID-19 }\end{array}$} & $\begin{array}{l}\text { No } \\
\text { Yes }\end{array}$ & 4 & 9 & 16.3 & \multirow[b]{2}{*}{1.270} & \multirow[b]{2}{*}{0.260} \\
\hline & & 32 & 35 & 100 & & \\
\hline \multirow[t]{4}{*}{$\begin{array}{l}\text { How do you improve } \\
\text { immunity }\end{array}$} & $\begin{array}{l}\text { Adequate } \\
\text { sleep }\end{array}$ & 2 & 12 & 17.5 & \multirow{4}{*}{$9 \cdot 301$} & \multirow{4}{*}{0.026} \\
\hline & $\begin{array}{l}\text { Eat ginger, } \\
\text { tamarind }\end{array}$ & 12 & 6 & 78.8 & & \\
\hline & Vitamin C & 9 & 8 & 100 & & \\
\hline & All the above & 13 & 18 & 56.3 & & \\
\hline
\end{tabular}

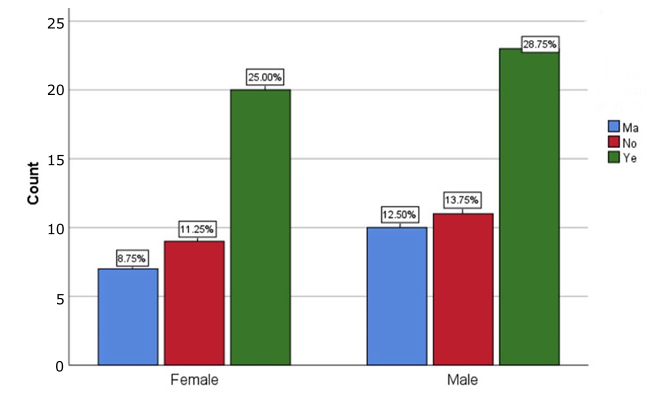

Figure 9: This bar graph shows the association between the gender and people aware of COVID-19 that travels through droplets. The X-Axis shows the gender and Y-Axis shows the responses. The green bar shows people who are aware of it, red shows people who are ignorant of the fact, and blue shows that people are not sure about COVID-19 travelling through droplets. $28.75 \%$ of males were aware that COVID-19 travels through droplets. There was not a significant difference in awareness between males and females. Chi-square test value is $0.140, P$-value $0.932(>0.05)$ (no significant difference)

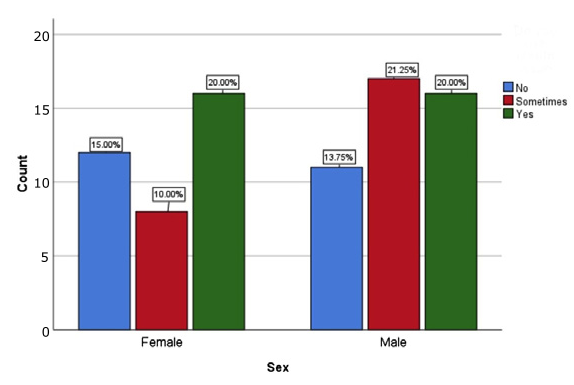

Figure 10: This graph shows the correlation between people who use mouthwash. The X-Axis shows gender and Y-Axis shows the responses. The green bar shows people who use mouthwash, red shows people who don't use mouthwash, and blue shows people who use it occasionally. There is an equal amount of people who use mouthwash in both the female and male population of the study. P-value is $0.285,(>0.05)$, Chisquare test value is 2.509 . This shows there no significant relationship between male and female responses regarding the use of mouthwash.

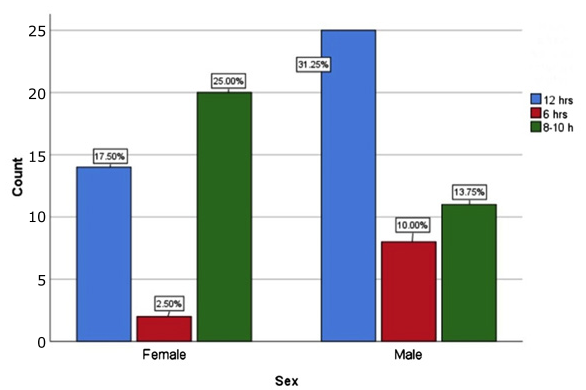

Figure 11: This graph shows the correlation between how often people change the water. The X-Axis shows gender and Y-Axis shows responses. The green bar shows people who change water for 8-10 hours, red for every 6 hrs, and blue for every $12 \mathrm{hrs}$. Most of the male population (31.25\%) change water for once in $12 \mathrm{hrs}$, while the female population mostly changes the water (25\%) for every 8-10 hours. P-value is 0.014 $(<0.05)$, Chi-square test value is 8.601 . This shows there is a significant relationship between male and female responses in regard to how often they change the water.

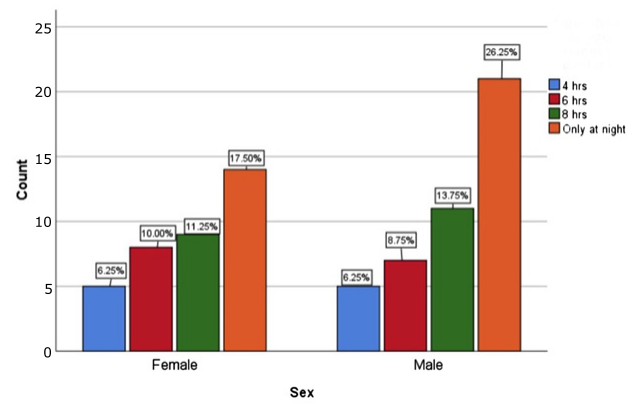

Figure 12: This graph shows the correlation between gender and how often they remove dentures. The X-Axis shows gender and $Y$-Axis shows responses. The orange bar shows where they remove it only at night, while the green bar shows they remove it for every $8 \mathrm{hrs}$, red bar for every $6 \mathrm{hrs}$, and blue bar for every $4 \mathrm{hrs}$. Most of them remove the dentures only at night which is $26.25 \%$ for males and $17.50 \%$ for females. Pvalue is $0.831(>0.05)$, Chi-square test value is 0.875 . There is no significance in male and female responses when correlated to how often they remove dentures. 


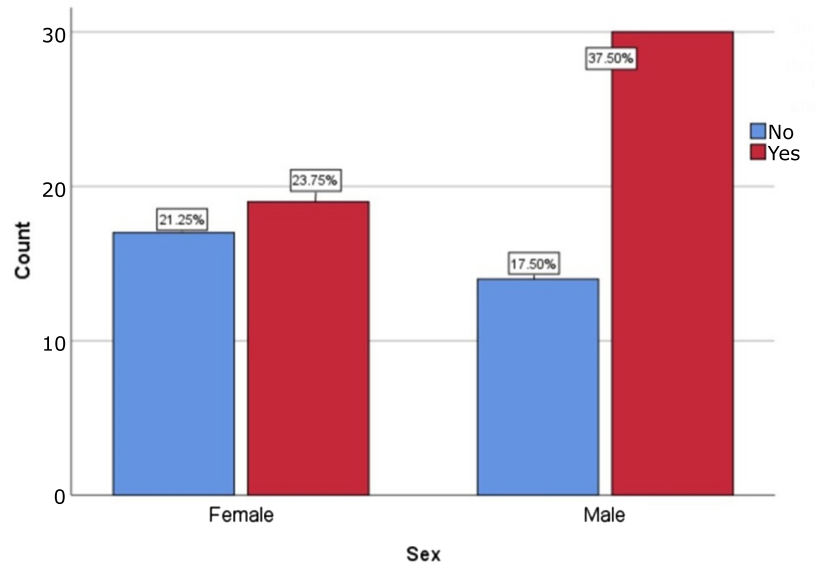

Figure 13: This graph shows the correlation between gender and people who keep dentures in a closed box. The $X$ Axis shows gender and Y-Axis shows responses. The red bar shows that people store the dentures in a closed box to prevent contamination and the awareness is more in males with $37.50 \%$ when compared to females at $23.75 \%$. P-value is $0.159(>0.05)$, Chi-square test value is 1.980 . This shows that there is no significant relation between the male and female responses in people who keep dentures in closed boxes.

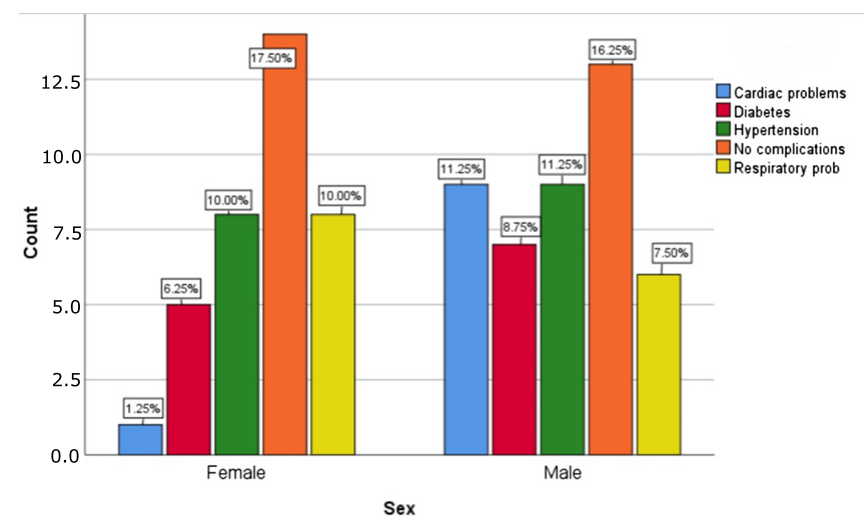

Figure 14: This graph shows the correlation between gender and people who suffer from any medical conditions. The $\mathrm{X}$-Axis shows the gender and $\mathrm{Y}$-Axis shows the responses. The yellow bar shows the respiratory problems, orange bar no complications, blue bar cardiac problems, green bar hypertension, and red bar for diabetes. Cardiac problems were shown to be more prevalent in males $(11.25 \%)$ when compared to females $(1.25 \%)$. Diabetes was more in the male population $(8.75 \%)$ while respiratory problems were more in females $(10 \%)$. P-value is $0.173(>0.05)$, Chi-square test value is 6.379 . There is no significant relation between male and female responses regarding their medical conditions.

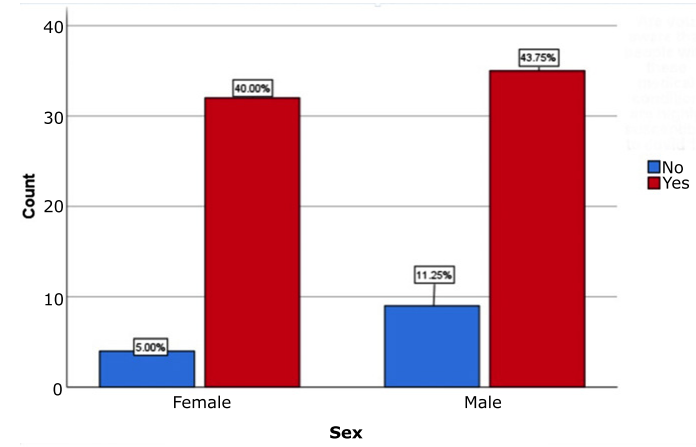

Figure 15: Correlation between gender and people who are aware that if they suffer from any medical issues that they are highly susceptible to COVID-19 infection. The X-Axis shows the gender and Y-Axis shows the responses. The red bar shows a positive response while the blue bar shows a negative response. Ignorance level was high in males with $11.25 \%$. $P$-value is 0.260 (>0.05), Chi-square test value is 1.270 . There is no significant relation between males and females regarding awareness of medical condition COVID-19.

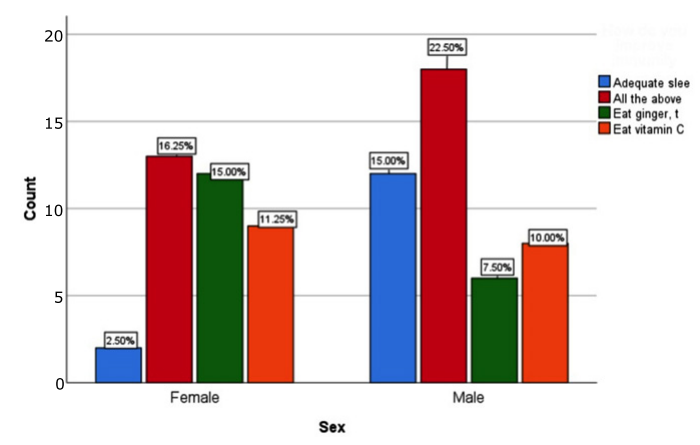

Figure 16: This graph shows the correlation between gender and people who are aware of the methods of improving immunity. The $\mathrm{X}$-Axis shows the gender and $\mathrm{Y}$-Axis shows the responses. The orange bar shows the methods of vitamin $\mathrm{C}$, green bar shows eating ginger, tamarind, blue bar shows adequate sleep and red bar shows all the above methods. Among the different methods available to improve immunity, the male population $(22.50 \%)$ were more aware that all the above methods lead to an improvement in immunity. P-value is $0.026(<0.05)$, Chi-square test value is 9.301 . There is a significant relation between male and female responses in awareness of methods taken to improve immunity.

Responses were collected and analyzed. Nearly 50\% were aware that COVID-19 traveled through droplets while some were doubtful and some were not aware of it (Figure 1). Nearly $40 \%$ use mouthwash regularly and $31.3 \%$ use it sometimes (Figure 2). Almost 50\% change water in which they store dentures every 12 hours, in order to protect them from infection (Figure 3 ). $43.8 \%$ of the population removes dentures only at night time which can aid in the advantage of less hand contamination of the denture (Figure 4). To protect the denture nearly $61.3 \%$ of the population had kept it in a closed box 
from (Figure 5), only $33.8 \%$ were found to have no medical complications (Figure 6). But the elderly population of about $83.8 \%$ with medically compromised conditions was aware that high susceptibility to getting infected by COVID-19 (Figure 7). Almost all of them were aware that they have to improve their immunity and take different measures so that they can protect themselves from the COVID-19 pandemic (Figure 8). Denture hygiene maintenance is important to reduce the incidence of bacterial and fungal infections ${ }^{20}$. Their maintenance like brushing and cleaning dentures can reduce the infection occurrence. In our study, about $40 \%$ use mouthwash and 50\% change water once in 12 hours. In the previous study done by Delaney et al and Teng et al. nearly 52\% maintained denture hygiene $^{21,22}$. As per the literature, the elderly population with medically compromised conditions, COVID-19 worsens the spread as they are more susceptible, henceforth maintaining the usage of dentures had a major role among denture wearers. In the present study, $83.8 \%$ of them knew the facts behind also in our survey, people with diabetes were $15 \%$, cardiac $12.5 \%$, hypertension $21.3 \%$, respiratory-related diseases $17.5 \%$ and without any medical complications were $33.8 \%$. The previous literature stated that $22 \%$ of diabetic patients had a poor survival rate in combating COVID-19. So diabetes becomes a major risk factor for COVID-19 ${ }^{23}$. Frequent removal of denture without hand hygiene can increase the risk of infection. Nearly $43.8 \%$ of the population removes it only at night which reduces the risk of transmission.

The cumulative response to each question along with the Chi-square test value and P-value is represented in Table 1. There was no significant association between the gender and the response of awareness of COVID-19 travelling through droplets (Figure 9), however, $28.75 \%$ of the male were aware that COVID-19 travels through droplets. In the next response knowing about the usage of mouthwash, there was no significant association between gender and the usage of mouthwash (Figure 10), i.e. equal amount of people used mouthwash in both the female and male population of the study. Comparing gender with how often they change the water for the denture, there was a statistically significant association between responses and how often they change the water, however, most of the male population $(31.25 \%)$ change water for once in $12 \mathrm{hrs}$, while the female population change water (25\%) for every 8-10 hours (Figure 11). Most of them remove the dentures only at night which is $26.25 \%$ for males and $17.50 \%$ for females; there was no significant association (Figure 12). Regarding the storage of dentures, the awareness is more among males with $37.50 \%$ when compared to females at $23.75 \%$ as most of the males kept in a closed box (Figure 13). Among the study population, the medically compromised conditions based on gender are represented (Figure 14). Based on medically compromised conditions, the level of awareness towards COVID-19, there was no significant association between responses and aware- ness of medical condition (Figure 15), however, Ignorance level was high in the male with $11.25 \%$. Regarding the awareness of immunity among denture wearers, it was found that there was a significant association between responses and awareness of methods of immunity (Figure 16), among the different methods available to improve immunity, the male population $(22.50 \%)$ were more aware of the different methods of improving immunity.

There was a reduction of infection of the denture by $13.8 \%$ by storing them overnight in water with cleansing tablets according to a previous study ${ }^{24}$. Also, when oral hygiene like mouthwash is being used, it reduces the risk of pneumonia in ill patients ${ }^{25}$. When mouthwash can reduce the risk of pneumonia it can simultaneously reduce the risk for COVID-19. Mouthwash can cause a $40 \%$ reduction in infection. In our study, nearly $40 \%$ use mouthwash regularly while $21 \%$ use it sometimes. Chlorhexidine mouth rinse is an adjunctive treatment for oral health. It also helps in the reduction of infection. When oral health is maintained no further occurrence of opportunistic infection occurs ${ }^{26}$. The COVID-19 has emerged as an extremely virulent pandemic, causing disruption of the lives of thousands of individuals all over the world. ${ }^{27}$ According to a study by Jonathan Chadwick it has been suspected that the use of mouthwash can alter the lipid layer which is the outer membrane of the COVID-19 virus. It damages the lipid layer rendering them from virulence. The spike layer which is responsible for infection when altered can lead to a reduction of infection from the pathogen. Also, interdental brushing can reduce the control of infection and help in maintaining better oral hygiene ${ }^{28}$.

When people are having oral inflammation it leads to infection of chronic obstructive pulmonary disease. This can lead to a loss of immunity. When there is loss of immunity it becomes the risk factor of COVID-19. Therefore when dentures were well cleaned and kept in overnight storage, the infection control is better according to previous literature. Hence, usage of mouthwash and daily change of water, cleanliness of denture, avoiding the frequent removal of the denture by hand can help in preventing the spread of infection. Hence oral hygiene is important as it reduces the risk of transmission of COVID-19.

\section{CONCLUSION}

Within the limitation of the study, the majority of denture wearers had awareness of denture cleansing and oral hygiene practices. As the elderly population is more prone to COVID-19, the patients should be motivated by the dentists about denture cleansing and the harmful effect of overnight wearing, such denture hygiene maintenance will aid patients in combating COVID-19. Therefore, dentists' role in telecommunication with denture wearer patients, regarding denture maintenance can reduce the risk of infection. 


\section{ACKNOWLEDGEMENT}

Authors acknowledge the immense help received from the scholars whose articles are cited and included in references of this manuscript. The authors are also grateful to authors / editors / publishers of all those articles, journals and books from where the literature for this article has been reviewed and discussed.

\section{Conflict of Interest}

The authors declare that they have no conflict of interest.

\section{Funding Information}

None

\section{REFERENCES}

1. Da Rosa Possebon AP, Marcello-Machado RM, Bielemann AM, Schuster AJ, De Rezende PL, Faot F. Masticatory function of conventional complete denture wearers changing to 2-implant retained mandibular overdentures:Clinical factor influences after 1 year of function. J Prosthodont Res. 2018; 62(4):479-84.

2. Ariga P, Nallaswamy D, Jain AR, Ganapathy DM. Determination of Correlation of Width of Maxillary Anterior Teeth using Extraoral and Intraoral Factors in Indian Population: A Systematic Review. World Journal of Dentistry. 2018;9:68-75. Available from: http://dx.doi.org/10.5005/jp-journals-10015-1509

3. Duraisamy R, Krishnan CS, Ramasubramanian H, Sampathkumar J, Mariappan S, Navarasampatti SA. Compatibility of Nonoriginal Abutments With Implants: Evaluation of Microgap at the Implant-Abutment Interface, With Original and Nonoriginal Abutments. Implant Dent. 2019;28(3):289-95.

4. Jyothi S, Robin PK, Ganapathy D, Others. Periodontal health status of three different groups wearing temporary partial denture. Research Journal of Pharmacy and Technology. 2017;10(12):4339-42.

5. Basha FYS, Ganapathy D, Venugopalan S. Oral Hygiene Status among Pregnant Women. Research Journal of Pharmacy and Technology.2018;11:3099. Available from: http://dx.doi. org/10.5958/0974-360x.2018.00569.3

6. Ganapathy D, Sathyamoorthy A, Ranganathan H, Murthykumar K. Effect of Resin Bonded Luting Agents Influencing Marginal Discrepancy in All Ceramic Complete Veneer Crowns. J Clin Diagn Res. 2016 ;10(12):67-70.

7. Ranganathan H, Ganapathy DM, Jain AR. Cervical and Incisal Marginal Discrepancy in Ceramic Laminate Veneering Materials: A SEM Analysis. Contemp Clin Dent. 2017;8(2):272-78.

8. Kannan A, Venugopalan S, Ganapathy DM. Effect of Coated Surfaces influencing Screw Loosening in Implants: A Systematic Review and Meta-analysis. World journal of Dentistry 2017;8(6):496-502.

9. De Oliveira Junior NM, Rodriguez LS, Mendoza Marin DO, Paleari AG, Pero AC, Compagnoni MA. Masticatory performance of complete denture wearers after using two adhesives: a crossover randomized clinical trial. J Prosthet Dent. 2014;112(5):1182-87.

10. Testarelli L, Aversa L, Dolci G. The challenge of severe acute respiratory syndrome (SARS) in dentistry. Minerva Stomatol. $2004 ; 53(7): 389-402$.

11. Volgenant CMC, Persoon IF, Ruijter RAG, Soet JJ. Infection control in dental health care during and after the SARS CoV
2 outbreak. Oral Diseases.2020;00:1-10. Available from: http:// dx.doi.org/10.1111/odi.13408

12. Montecino RE, Berent-Maoz B, Dorshkind K. Causes,consequences, and reversal of immune system aging. J Clin Invest. 2013;123(3):958-65.

13. Ashok V, Nallaswamy D, Benazir Begum S, Nesappan T. Lip Bumper Prosthesis for an Acromegaly Patient. A Clinical Report. J Indian Prosthodont Soc. 2014 ;14 (1):279-82.

14. Venugopalan S, Ariga P, Aggarwal P, Viswanath A. Case Report: Magnetically retained silicone facial prosthesis. Niger J Clin Pract. 2014;17(2):260-64.

15. Vijayalakshmi B, Ganapathy D. Medical management of cellulitis. J Pharm Res 2016;9(11):2067-70 Available from http:// www.indianjournals.com/ijor.aspx?target=ijor:rjpt\&volume=9 \&issue $=11$ \&article $=051$

16. Ashok V, Suvitha S. Awareness of all ceramic restoration in rural population. J Pharm Res 2016;9(10):91-93. http://www.indianjournals.com/ijor.aspx?target $=$ ijor:rjpt $\&$ volume $=9 \&$ issue $=10 \&$ article $=039 \&$ type $=$ pdf

17. Ajay R, Suma K, Ali SA, Kumar Sivakumar JS, Rakshagan V, Devaki V, et al. Effect of Surface Modifications on the Retention of Cement-retained Implant Crowns under Fatigue Loads: An In vitro Study. J Pharm Bioallied Sci. 2017;9(1):154-60.

18. Selvan SR, Ganapathy D. Efficacy of fifth generation cephalosporins against methicillin-resistant Staphylococcus aureusA review. Research Journal of Pharmacy and Technology. 2016;9(10):1815-18.

19. Subasree S, Murthykumar K, Dhanraj. Effect of Aloe Vera in Oral Health-A Review. Research Journal of Pharmacy and Technology. 2016;9(5):609-12.

20. Khasawneh S, Al-Wahadni A. Control of denture plaque and mucosal inflammation in denture wearers. J Ir Dent Assoc. 2002;48(4):132-8.

21. Delaney C, O’Donnell LE, Kean R, Sherry L, Brown JL, Calvert $\mathrm{G}$, et al. Interkingdom interactions on the denture surface: Implications for oral hygiene. Biofilms. 2019;1:100002.

22. Teng CJ, Lin SC, Chen JH, Chen Y, Kuo HC, Ho PS. The association between denture self-satisfaction rates and OHRQoL - a follow-up study. BMC Oral Health. 2020;20(1):140.

23. Hussain A, Ali I, Hassan Z. People with Diabetes Mellitus: Soft target for COVID-19 infection.Pakistan Journal of Medical Sciences. 2020;36(4):3-5 Available from: http://dx.doi. org/10.12669/pjms.36.covid19-s4.2629

24. Verhaeghe TV, Wyatt CC, Mostafa NZ. The effect of overnight storage conditions on complete denture colonization by Candida albicans and dimensional stability: A systematic review. J Prosthet Dent 2020;124(2):176-82. http://dx.doi.org/10.1016/j.prosdent.2019.07.014

25. Hua F, Xie H, Worthington HV, Furness S, Zhang Q, Li C. Oral hygiene care for critically ill patients to prevent ventilator associated pneumonia. Cochrane Database of Systematic Review. 2016;(10):1-136.

26. James P, Worthington HV, Parnell C, Harding M, Lamont T, Cheung A, et al. Chlorhexidine mouthrinse as an adjunctive treatment for gingival health. Cochrane Database Syst Rev. 2017; 3(3):CD008676.

27. Sana P, Shraddha J. Pathophysiologic Enigma of COVID-19 Pandemic with Clinical Correlates. Int J Cur Res Rev. 2020;12(13):3337 http://dx.doi.org/10.31782/IJCRR.2020.12136

28. De Souza RF, De Freitas Oliveira PH, Lovato da Silva CH, Abu-Nabaa L, Fedorowicz Z, Gurgan CA. Interventions for cleaning dentures in adults. Cochrane Database Syst Rev. 2009; 7(4):CD007395. 